EREM 74/4

Journal of Environmental Research, Engineering and Management Vol. 74 / No. 4 / 2018 pp. $87-94$ DOI 10.5755/j01.erem.74.4.19875 (c) Kaunas University of Technology
The Impact of Landfill Gas Emission on Morphological Parameters of Leaves in "Kolomna" MSW Landfill

Received 2018/01

Accepted after revision 2018/02

\title{
The Impact of Landfill Gas Emission on Morphological Parameters of Leaves in "Kolomna" MSW Landfill
}

\author{
Mamadzhanov Roman, Khaustov Aleksandr, Redina Margarita, Nigmatzyanova Yulia \\ Ecological Department, RUDN University, Moscow, Russia, 115093, Podolskoye highway, 8-5
}

\section{Umarov Mykhadi}

Complex Institute Named After Kh. I. Ibragimov of the Russian Academy of Sciences,

Groznyi, Chechen Republic, Russia, 364051, Staropromyslovskoe highway, 21 a

Corresponding author: daddy_roma@mail.ru

Ecological Department of RUDN University, Moscow, Russia, 115093, Podolskoye highway, 8-5

The article presents the results of measurements of the atmospheric quality in "Kolomna" municipal solid waste (MSW) landfill, the visual assessment of plant life and analysis of morphological parameters of leaves, which grow in experimental and control areas, and the 3D concentration spreading of landfill gas emission. The main idea is to identify the influence of landfill gas emission and morphological parameters of leaves, which grow near the landfill. By factor analysis, we proved the factor value of landfill gas emissions on the morphological parameters of leaves and revealed the main factors which could change the morphological parameters of leaves in experimental and control areas.

Keywords: waste, MSW landfill, landfill gas emission, plant life assessment, morphological parameters of leaves, factor analysis, factor value.

\section{Introduction}

Currently, one of the most popular methods of the municipal solid waste (MSW) disposal is landfill disposal (Cesoniene et al., 2017; Owusu et al., 2017).
This method is much cheaper for many industrialized countries (Maamari et al., 2017) because all the collected waste is immediately sent to landfills. For 
example, in Moscow region, more than 90\% of MSW is delivered to a dumpsite (Mamadzhanov and Latushkina, 2016). However, from the environmental point of view, this method is very dangerous for the environment, because all this waste after its decomposition could create new toxic compounds such as landfill gas emissions and leachate (Zaltauskaite and Vaitonyte, 2016). It is important that today in Moscow region there are pipes collecting leachate and landfill gas in more than $50 \%$ of the existing landfills (Gonopolsky et al., 2009).

As a result, most of the emissions enter the environment and are consumed or absorbed by the atmosphere, soil cover, surface and groundwater, plants, animals and other living organisms. It is noteworthy that one of the main organisms, which is very sensitive to the impact of pollution emissions, is plant communities (Pavlov, 2014; Chen, 2016). This could be explained by activities of leaves and roots when they take up and store oxygen, nutrients and water resources (Kotovicova, 2011; Sujetovieny, 2016).

The aim of our research is to evaluate the impact of gas emissions, particularly "Kolomna" landfill gas emissions, on the morphological parameters of leaves which grow near "Kolomna" MSW landfill.

"Kolomna" MSW landfill is located at a distance of 3.5 $\mathrm{km}$ from Kolomna city in Moscow region, in the southwest direction. The area of the landfill is 13.2 ha (Fig. 2).

\section{Methods}

Our studies involve field testing, laboratory analysis, GIS and mathematical data processing (Fig. 1).

Field testing includes environmental monitoring of the atmospheric quality involving control of concentration of carbon monoxide (CO), nitrogen oxide (NO), nitrogen dioxide $\left(\mathrm{NO}_{2}\right)$, hydrogen sulphide $\left(\mathrm{H}_{2} \mathrm{~S}\right)$, chlorine $(\mathrm{CL})$, benzene $\left(\mathrm{C}_{6} \mathrm{H}_{6}\right)$, toluene $\left(\mathrm{C}_{7} \mathrm{H}_{8}\right)$, methanal $\left(\mathrm{CH}_{2} \mathrm{O}\right)$, ethanal $\left(\mathrm{C}_{2} \mathrm{H}_{4} \mathrm{O}\right)$ and carbon disulphide $\left(\mathrm{CS}_{2}\right)$; visual plant life assessment, phenophases of plant and morphological parameters of tree trunks (height and diameter of tree trunks).

For the environmental monitoring of the atmospheric quality, we used a gas analyzer GANG-4 (RD 52.04.186-89). We marked 33 sampling sites in "Kolomna" MSW landfill (Fig. 2). For each sample, we performed three measurements of $\mathrm{CO}, \mathrm{NO}, \mathrm{NO}_{2}, \mathrm{H}_{2} \mathrm{~S}$, $\mathrm{CL}, \mathrm{C}_{6} \mathrm{H}_{6}, \mathrm{C}_{7} \mathrm{H}_{8}, \mathrm{CH}_{2} \mathrm{O}, \mathrm{C}_{2} \mathrm{H}_{4} \mathrm{O}$ and $\mathrm{CS}_{2}$ concentrations. In addition, we determined the height of "Kolomna" MSW landfill and identified tree trunks with laser rangefinder Bosh GLM 40. In total, we collected 1,089 data sets.

Moreover, for the visual assessment of plant life and morphological parameters of leaves we observed four different areas (Fig. 2). Each area was $20 \mathrm{~m}^{2}$. The experimental areas were situated near the landfill (inside the sanitary boundary); meanwhile, the control

\section{Fig. 1}

The scheme of the used methods

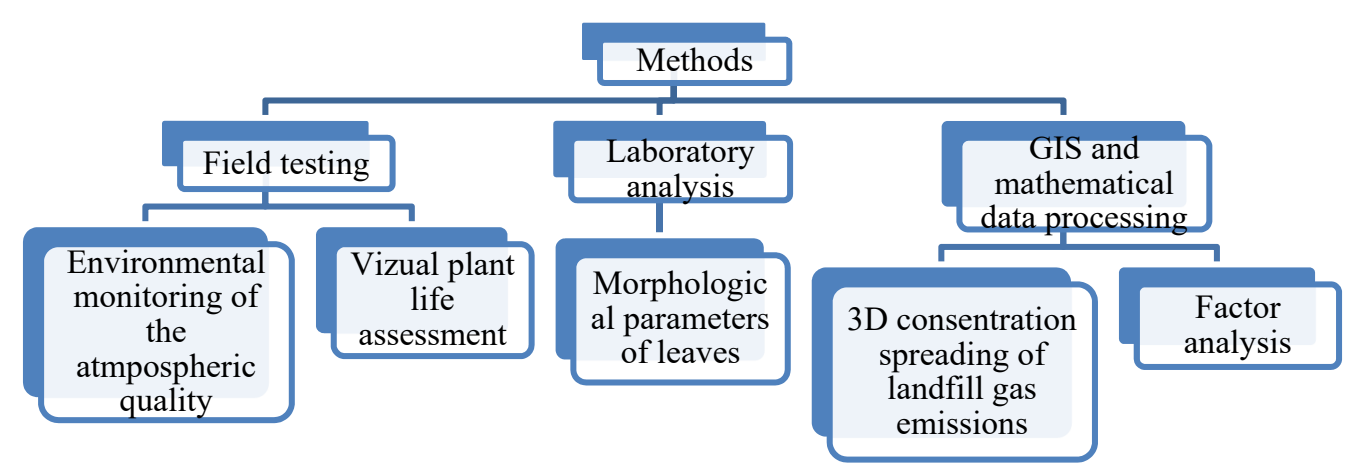




\section{Fig. 2}

Sampling sites, experimental and control areas in «Kolomna» MSW landfill

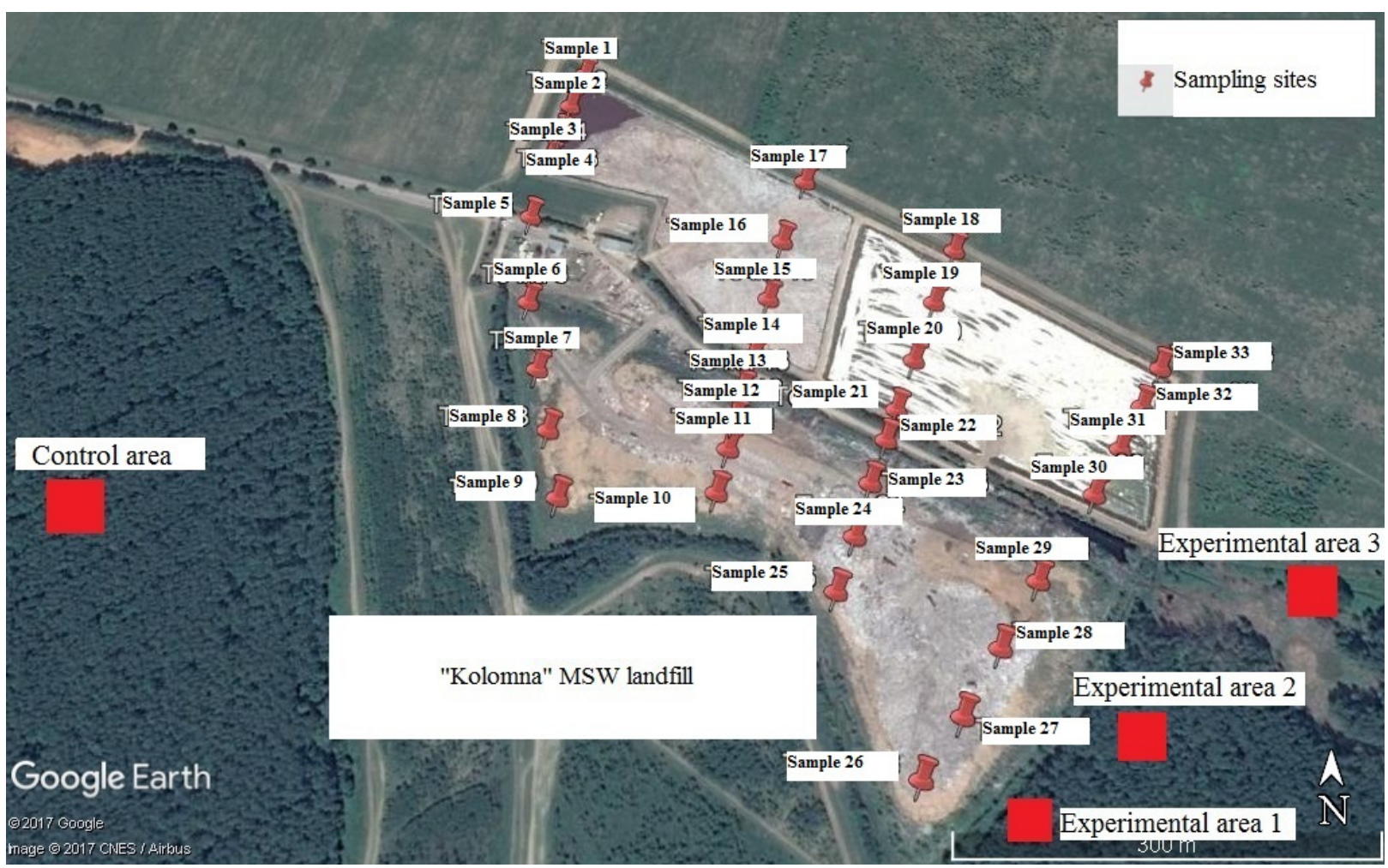

area was located far away from the landfill (outside the sanitary boundary).

To compare the impact of "Kolomna" landfill gas emission on the morphological parameters of leaves, we also took three measurements of $\mathrm{CO}, \mathrm{NO}, \mathrm{NO}_{2}, \mathrm{H}_{2} \mathrm{~S}$, $\mathrm{CL}, \mathrm{C}_{6} \mathrm{H}_{6}, \mathrm{C}_{7} \mathrm{H}_{8}, \mathrm{CH}_{2} \mathrm{O}, \mathrm{C}_{2} \mathrm{H}_{4} \mathrm{O}$ and $\mathrm{CS}_{2}$ concentrations in experimental and control areas.

For the visual plant life assessment, at first, we identified tree species according to Bogolubov (Bogolyubov, 2002) and revealed the phenophases of these plants according to Bykharina (Bykharina and Dvoeglazova, 2010) and Umarov (Umarov and Taisumov, 2012). From the environmental point of view and for conserving young trees, we deliberately did not identify the age of trees. In addition, the species diversity research was carried out by the Margalef diversity index (Bogolyubov, 1998). Phytocenoises formula was constructed by the method of Bogolyubov (2002), where we calculated trees and schrubs on experimental and controlled areas.
Secondly, we observed the morphological parameters of tree trunks, particularly the height $(\mathrm{m})$ and the diameter $(\mathrm{cm})$ of trees and collected 10 leaves from each tree in experimental and control areas. Afterwards, we took those samples into a lab. Laboratory analysis included the study of morphological parameters on the right and on the left sides of leaves, particularly the length $(\mathrm{cm})$, width $(\mathrm{cm})$, thickness $(\mu \mathrm{m})$, weight $(\mathrm{g})$ and area $\left(\mathrm{cm}^{2}\right)$ of a leaf, as well as the length between the first and the second vein of a leaf $(\mathrm{cm})$, the length between the tip of a leaf and the end of the fourth vein of a leaf $(\mathrm{cm})$, the distance between the second vein of a leaf and the blade of a leaf $(\mathrm{cm})$, the width between the midrib and the margin of a leaf $(\mathrm{cm})$, the distance between the first and the second blade of a leaf $(\mathrm{cm})$, and the angle between the midrib and the second vein of a leaf $\left({ }^{\circ}\right)$. It should be noted, that these parameters are an indication of plant life conditions in environmental changes (Bogolyubov, 1998).

It should be noted that GIS data processing was 
conducted in Surfer version 12. Mathematical data processing was carried out by factor analysis in SPSS version 17.0. Using the method of full explained variances, we identified the main factors which could change the morphological parameters of leaves in experimental and control areas (Lakin, 1990). By the factor value, we determined the structure of each factor (with factor value more than 0.5) and showed the factor value of the landfill gas emission and the morphological parameters of leaves variations in experimental and control areas.

\section{Results}

The results of the environmental monitoring of the atmospheric quality in "Kolomna" MSW landfill are shown in Table 1.

As shown in Table 1, the concentrations of toluene $\left(\mathrm{C}_{7} \mathrm{H}_{8}\right)$ and ethanal $\left(\mathrm{C}_{2} \mathrm{H}_{4} \mathrm{O}\right)$ have always been higher from 5 to 63 times in comparison with MAC. Taking into account the average and maximum values, the concentration of nitrogen dioxide $\left(\mathrm{NO}_{2}\right)$, benzene
$\left(\mathrm{C}_{6} \mathrm{H}_{6}\right)$ and carbon disulphide $\left(\mathrm{CS}_{2}\right)$ was higher from 1 to 20 times than MAC. Such increased concentrations are the result of the intensive aerobic and anaerobic processes of organic (inorganic) decomposition of waste in "Kolomna" MSW landfill. It is important that the concentration of the landfill gas emission in experimental areas was particularly the same while the concentration of the landfill gas emission in the control area was significantly lower than MAC.

The 3D consentration spreading of the landfill gas emission in "Kolomna" MSW landfill is presented in Fig. 3.

As shown in Fig. 3, the concentration of chlorine (CL), benzene $\left(\mathrm{C}_{6} \mathrm{H}_{6}\right)$, methanal $\left(\mathrm{CH}_{2} \mathrm{O}\right)$ and ethanal $\left(\mathrm{C}_{2} \mathrm{H}_{4} \mathrm{O}\right)$ increased over the northwestern side of the landfill. Such distribution of concentrations is associated with the placement of polymer materials and other industrial waste (in the southeastern part of the landfill). Meanwhile, the emissions of monoxide (CO), nitrogen oxide (NO), nitrogen dioxide $\left(\mathrm{NO}_{2}\right)$, carbon disulphide $\left(\mathrm{CS}_{2}\right)$, and toluene $\left(\mathrm{C}_{7} \mathrm{H}_{8}\right)$ increased to the southeast of the landfill. It is important that in this territory the amount of organic components of waste, particularly food waste, increases considerably.

\section{Table 1}

**The results of landfill gas emission in "Kolomna" MSW landfill

\begin{tabular}{|c|c|c|c|c|}
\hline Toxic compounds & Min & Average & Max & $\operatorname{MAC}^{*}\left(\mathrm{mg} / \mathrm{m}^{3}\right)$ \\
\hline 1 & 2 & 3 & 4 & 5 \\
\hline $\mathrm{CO}$ & 0.0390 & 0.0580 & 0.0770 & 5.000 \\
\hline NO & 0.4175 & 0.0110 & 0.0206 & 0.400 \\
\hline $\mathrm{NO}_{2}$ & 0.0830 & 1.8370 & 3.7965 & 0.200 \\
\hline $\mathrm{H}_{2} \mathrm{~S}$ & 0.0062 & 0.2500 & 0.1050 & 0.008 \\
\hline $\mathrm{CL}$ & 0.0127 & 0.0180 & 0.0270 & 0.100 \\
\hline $\mathrm{C}_{6} \mathrm{H}_{6}$ & 0.0036 & 7.1020 & 21.266 & 0.300 \\
\hline $\mathrm{C}_{7} \mathrm{H}_{8}$ & 5.4666 & 7.3926 & 8.5660 & 0.600 \\
\hline $\mathrm{CH}_{2} \mathrm{O}$ & 0.0057 & 0.0770 & 0.1657 & 0.035 \\
\hline $\mathrm{C}_{2} \mathrm{H}_{4} \mathrm{O}$ & 50.200 & 55.800 & 63.500 & 0.010 \\
\hline $\mathrm{CS}_{2}$ & 0.4933 & 10.100 & 20.700 & 0.030 \\
\hline
\end{tabular}

Note: *MAC - the maximum allowable concentration **in proportion of MAC. 


\section{Fig. 3}

The 3D consentration spreading of the landfill gas emission in "Kolomna" MSW landfill

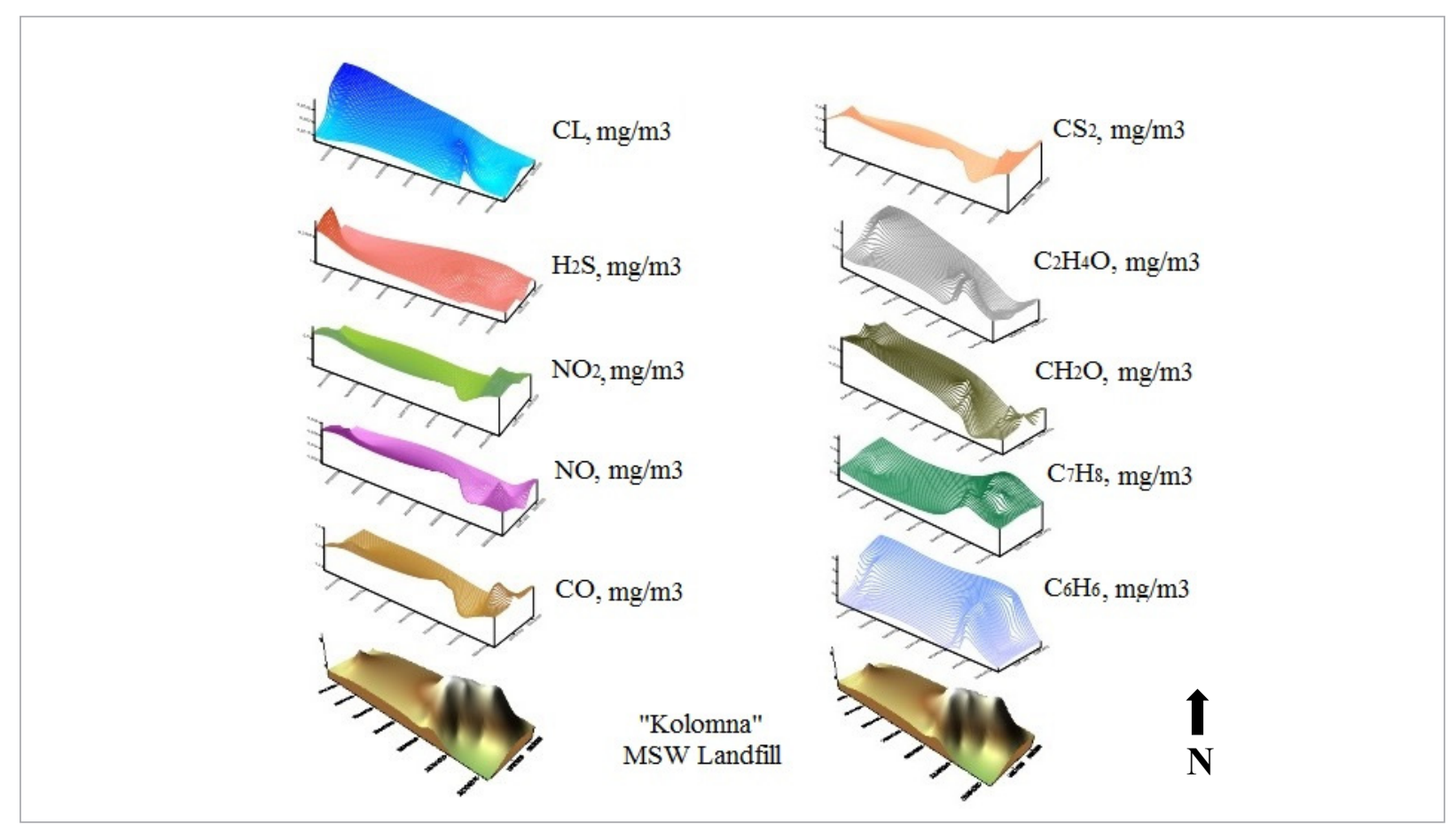

The visual plant assessment in experimental and control areas allowed us to identify six species of trees and two species of shrubs (Table 2).

Table 2 shows that less species diversity is presented in experimental areas 2 and 3 , which could be related to leachate activities of the landfill as it is accumulated in low relief areas towards the northeast.

\section{Table 2}

The phytocenosis formula in experimental and control areas (the number of trees and shrubs species)

\begin{tabular}{l|l}
\multicolumn{1}{c|}{ Area } & \multicolumn{1}{c}{ Formula* } \\
\hline \multicolumn{1}{c|}{1} & \multicolumn{1}{c}{2} \\
\hline Experimental 1 & 1An1Sc1Rm1Rc \\
\hline Experimental 2 & 1Sc1Bp \\
\hline Experimental 3 & 1Sc1An1Pt \\
\hline Control & 1Ap1Sc1Sa1Pt \\
\hline
\end{tabular}

*Note: Ap - Acer platanoides, Sc - Salix caprea, Sa - Salix alba, Pt Populus tremula, An - Acer negundo, Rm - Rosa majalis, Rc - Rosa canina, Bp-Betula pendula 1,2...n-the number of trees (shrubs).
From the biological point of view, all these plants can be characterized by deciduous and unpretentious species which can grow in acidified soils (Belyaeva, 2015). Moreover, all these plants can be characterized by relatively young trees.

For the visual assessment of plant life and the study of species diversity, we also observed the morphological parameters of tree trunks, identified the phenophases of plants and calculated the Margalef diversity index (Table 3).

As shown in Table 3, the experimental area 1 and control area had the largest species diversity index (2.164). In addition, each of these territories had four trees species with the relatively standard height and diameter of tree trunks; furthermore, there was no visible damage of the trees. Meanwhile, experimental area 2 had the smallest species diversity index (1.443) with the relatively small height and diameter of tree trunks.

The main factors which could change the morphological parameters of leaves in experimental and control areas are presented in Fig. 4. 


\section{Table 3}

The morphological parameters of tree trunks, phenophases of these plants and the Margalef diversity index in experimental and control areas

\begin{tabular}{|c|c|c|c|c|}
\hline Tree species & Height of a tree trunk $(m)$ & $\begin{array}{l}\text { Diameter of a tree trunk } \\
\qquad(\mathrm{cm})\end{array}$ & Phenophases & $D^{*}$ \\
\hline 1 & 2 & 3 & 4 & 5 \\
\hline \multicolumn{5}{|c|}{ Experimental area 1} \\
\hline Acer negundo & 2.9 & 6.1 & The first leaf & \multirow{4}{*}{2.164} \\
\hline Salix caprea & 5.8 & 4.4 & All leaves unfolded & \\
\hline Rosa majalis & 1.6 & 3.8 & All leaves unfolded & \\
\hline Rosa canina & 1.2 & 3.1 & All leaves unfolded & \\
\hline \multicolumn{5}{|c|}{ Experimental area 2} \\
\hline Salix caprea & 2.3 & 5.3 & All leaves unfolded & \multirow{2}{*}{1.443} \\
\hline Betula pendula & 2.3 & 2.7 & All leaves unfolded & \\
\hline \multicolumn{5}{|c|}{ Experimental area 3} \\
\hline Salix caprea & 5.1 & 5.2 & All leaves unfolded & \multirow{2}{*}{1.821} \\
\hline Acer negundo & 5.1 & 14.2 & All leaves unfolded & \\
\hline Populus tremula & 4.3 & 18.2 & All leaves unfolded & \\
\hline \multicolumn{5}{|c|}{ Control area } \\
\hline Acer platanoides & 2.6 & 5.3 & All leaves unfolded & \multirow{4}{*}{2.164} \\
\hline Salix caprea & 2.2 & 9.4 & The first flower & \\
\hline Salix alba & 13.1 & 19.3 & All leaves unfolded & \\
\hline Populus tremula & 2.7 & 9.4 & All leaves unfolded & \\
\hline
\end{tabular}

*Margalef diversity index

Fig. 4

Percentage of the total variances of the identified factors

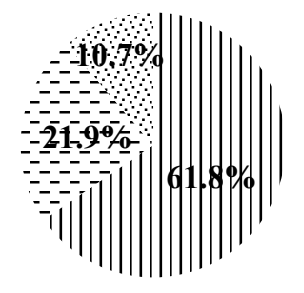

I Factor 1

- Factor 2

Factor 3

As seen, we obtained three groups of factors with certain percentage of the total variances. The total percentage of the variances of these factors is $94.4 \%$ because we did not take into account some factors such as climatic and soil conditions, organic concentrations of waste and other parameters (6.6\%). In addition, we determined the structure of each factor and showed the factor value between the distribution of toxic compounds and the morphological parameters of leaves variation in experimental and control areas (Table 4).

It should be emphasized that factor 1 is one of the important factors (61.8\% of the total variance), which consists of the landfill gas emission $\left(\mathrm{CO}, \mathrm{NO}_{2}, \mathrm{CL}, \mathrm{C}_{6} \mathrm{H}_{6}\right.$, $\mathrm{C}_{7} \mathrm{H}_{8}, \mathrm{C}_{2} \mathrm{H}_{4} \mathrm{O}$ and $\mathrm{CS}_{2}$ ) and almost all the morphological parameters of leaves, with the factor value more than 0.6 (Table 4). The structure of factor 2 (the total variance is $21.9 \%$ ) depends on the NO concentration (0.665) distribution and thickness of leaves (0.838). Consequently, the morphological parameters of leaves, which grow near MSW landfill, especially width, thickness, length between the tip of a leaf and the end of the fourth vein of a leaf, and distance between the second vein of a leaf and the blade of a leaf, are closely related (the factor value is 0.8 ) to the emission of landfill gas into the atmosphere. The structure of factor 2 depends on the $\mathrm{H}_{2} \mathrm{~S}$ concentration distribution, which could be 


\section{Table 4}

The factor value of the landfill gas emission and the morphological parameters of leaves

\begin{tabular}{|c|c|c|c|c|c|c|c|c|}
\hline \multicolumn{9}{|c|}{ Landfill gas emission } \\
\hline \multirow{11}{*}{$\begin{array}{c}\bar{c} \\
\bar{t} \\
\stackrel{0}{\leftarrow}\end{array}$} & Parameter & Value & \multirow{11}{*}{ 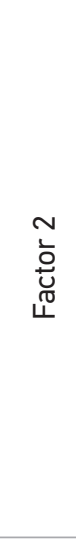 } & Parameter & \multirow{2}{*}{$\begin{array}{l}\text { Value } \\
0.384\end{array}$} & \multirow{11}{*}{ 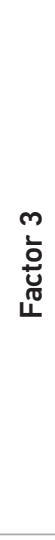 } & Parameter & Value \\
\hline & $\mathrm{CO}$ & 0.596 & & $\mathrm{CO}$ & & & CO & 0.369 \\
\hline & NO & 0.430 & & NO & 0.665 & & NO & 0.034 \\
\hline & $\mathrm{NO}_{2}$ & 0.601 & & $\mathrm{NO}_{2}$ & 0.308 & & $\mathrm{NO}_{2}$ & 0.391 \\
\hline & $\mathrm{CL}$ & 0.629 & & $\mathrm{CL}$ & 0.386 & & $\mathrm{CL}$ & 0.376 \\
\hline & $\mathrm{H}_{2} \mathrm{~S}$ & 0.175 & & $\mathrm{H}_{2} \mathrm{~S}$ & 0.136 & & $\mathrm{H}_{2} \mathrm{~S}$ & 0.890 \\
\hline & $\mathrm{CS}_{2}$ & 0.705 & & $\mathrm{CS}_{2}$ & 0.416 & & $\mathrm{CS}_{2}$ & 0.481 \\
\hline & $\mathrm{C}_{6} \mathrm{H}_{6}$ & 0.602 & & $\mathrm{C}_{6} \mathrm{H}_{6}$ & 0.554 & & $\mathrm{C}_{6} \mathrm{H}_{6}$ & 0.448 \\
\hline & $\mathrm{C}_{7} \mathrm{H}_{8}$ & 0.703 & & $\mathrm{C}_{7} \mathrm{H}_{8}$ & 0.474 & & $\mathrm{C}_{7} \mathrm{H}_{8}$ & 0.073 \\
\hline & $\mathrm{CH}_{2} \mathrm{O}$ & 0.675 & & $\mathrm{CH}_{2} \mathrm{O}$ & 0.564 & & $\mathrm{CH}_{2} \mathrm{O}$ & 0.054 \\
\hline & $\mathrm{C}_{2} \mathrm{H}_{4} \mathrm{O}$ & 0.311 & & $\mathrm{C}_{2} \mathrm{H}_{4} \mathrm{O}$ & 0.587 & & $\mathrm{C}_{2} \mathrm{H}_{4} \mathrm{O}$ & 0.074 \\
\hline \multicolumn{9}{|c|}{ *Morphological parameters of leaves } \\
\hline \multirow{20}{*}{$\begin{array}{l}\overline{\bar{z}} \\
\overline{\tilde{U}} \\
\text { L }\end{array}$} & Parameter & Value & \multirow{20}{*}{ 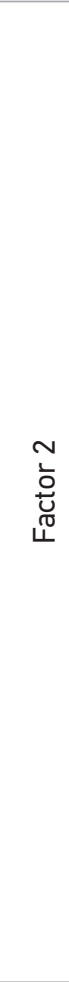 } & Parameter & Value & \multirow{20}{*}{ 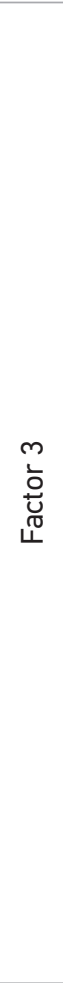 } & Parameter & Value \\
\hline & 1 & 0.730 & & 1 & 0.029 & & 1 & 0.149 \\
\hline & 2 & 0.939 & & 2 & 0.006 & & 2 & 0.226 \\
\hline & 3 & 0.036 & & 3 & 0.838 & & 3 & 0.338 \\
\hline & 4 & 0.876 & & 4 & 0.369 & & 4 & 0.210 \\
\hline & 5 & 0.845 & & 5 & 0.076 & & 5 & 0.101 \\
\hline & 6 & 0.846 & & 6 & 0.038 & & 6 & 0.358 \\
\hline & 7 & 0.872 & & 7 & 0.247 & & 7 & 0.115 \\
\hline & 8 & 0.845 & & 8 & 0.136 & & 8 & 0.124 \\
\hline & 9 & 0.877 & & 9 & 0.428 & & 9 & 0.083 \\
\hline & 10 & 0.745 & & 10 & 0.542 & & 10 & 0.158 \\
\hline & 11 & 0.912 & & 11 & 0.159 & & 11 & 0.170 \\
\hline & 12 & 0.596 & & 12 & 0.230 & & 12 & 0.146 \\
\hline & 13 & 0.810 & & 13 & 0.316 & & 13 & 0.097 \\
\hline & 14 & 0.492 & & 14 & 0.073 & & 14 & 0.156 \\
\hline & 15 & 0.912 & & 15 & 0.088 & & 15 & 0.252 \\
\hline & 16 & 0.612 & & 16 & 0.599 & & 16 & 0.050 \\
\hline & 17 & 0.801 & & 17 & 0.286 & & 17 & 0.032 \\
\hline & 18 & 0.462 & & 18 & 0.673 & & 18 & 0.094 \\
\hline & 19 & 0.314 & & 19 & 0.221 & & 19 & 0.532 \\
\hline
\end{tabular}

*1 - length; 2 - width; 3 - thickness; 4 - weight; 5 - area; 6 - the length of the first vein of a leaf (the left side); 7 - the length of the second vein of a leaf (the left side); 8 - the length of the first vein of a leaf (the right side); 9 - the length of the first vein of a leaf (the right side); 10 - the length of the second vein of a leaf (the right side); 11 - the length of the first vein of a leaf (the right side); 12 - the length of the second vein of a leaf (the right side); 13 - the length between the tip of a leaf and the end of the fourth vein of a leaf (the left side); 14 - the length between the tip of a leaf and the end of the fourth vein of a leaf (the right side); 15 - the distance between the second vein of a leaf and the blade of a leaf (the left side); 16 - the distance between the second vein of a leaf and the blade of a leaf (the left side); 17 - the distance between the second vein of a leaf and the blade of a leaf (the right side); 18 - the width between the midrib and the margin of a leaf (the left side); 19 - the width between the midrib and the margin of a leaf (the right side); 20 - the angle between the midrib and the second vein of a leaf (the left side); 21 the angle between the midrib and the second vein of a leaf (the right side). 
explained by natural aerobic and anaerobic processes that occur in the soil cover in experimental and control areas; this factor does not influence the variation of the morphological parameters of leaves.

In conclusion, the concentration of toxic compounds in "Kolomna" MSW landfill is significantly higher than MAC, by more than 1.5 times by nitrogen dioxide $\left(\mathrm{NO}_{2}\right)$, by $7-10$ times by benzene $\left(\mathrm{C}_{6} \mathrm{H}_{6}\right)$, toluene $\left(\mathrm{C}_{7} \mathrm{H}_{8}\right)$ and ethanal $\left(\mathrm{C}_{2} \mathrm{H}_{4} \mathrm{O}\right)$. Such distribution creates a new anthropogenic area, especially in terms of habitats for plants. In these areas (experimental area 2 and 3 ), we identified the smallest species diversity index (1.443) with the relatively small height and diameter of tree trunks. Furthermore, we found that the high factor value $(>0.6)$ of the landfill gas emission variation, such as ( $\mathrm{CO}, \mathrm{NO}_{2}, \mathrm{CL}, \mathrm{C}_{6} \mathrm{H}_{6}, \mathrm{C}_{7} \mathrm{H}_{8}, \mathrm{C}_{2} \mathrm{H}_{4} \mathrm{O}$ and $\mathrm{CS}_{2}$ ), and the variation of the morphological parameters of leaves, especially width, thickness, tlength between the tip of a leaf and the end of the fourth vein of a leaf,

\section{References}

Adam Gonopolsky, Anna Matyagina, Arthemy Kiselev, Sergey Osadchiy, Andrey Tsybin. (2009). Ecological and economic analysis of waste management systems: TEIS, $240 \mathrm{p}$.

Aleksander Bogolyubov (1998). Study of the vertical structure of the forest. http://karpolya.ru

Aleksander Bogolyubov (2002). Assessment of the ecological status of the forests by asymmetry of leaves. Publishing: Ecosystem, $10 \mathrm{p}$.

Gennady Lakin. (1990). Biometrics. Publishing: Higher education school, $352 \mathrm{p}$.

Irina Bykharina, Alexandra Dvoeglazova. (2010). Bioecological features of herbaceous and woody plants in the city. Publishing: Udmurt state University, 184 p. http://elibrary.udsu.ru

Ivan Pavlov (2014). Formation of fluorine technogenic anomalies in above-ground ecosystems of Siberia: Biological sorption, monitoring, possibility of lowering the negative impact. Contemporary Problems of Ecology, Volume 7, № 3, Pages 353-352. https://doi.org/10.1134/S1995425514030147

Jurate Zaltauskaite and Iveta Vaitonyte (2016). Toxicological assessment of closed municipal solid-waste landfill impact on the environment. Environmental Research, Engineering and Management, Volume 72, № 4, Pages 8-16. https://doi. org/10.5755/j01.erem.72.4.16555

Laima Cesoniene, Midona Dapkiene, Daiva Sileikiene, Vaiva Rekasiene (2017). Impact of Plungè City wastewater on water and distance between the second vein of a leaf and the blade of a leaf, are classified into one group of factors and have a heavy factor load. Consequently, we can assume that the long-term impact of "Kolomna" landfill gas emission on the morphological parameters of leaves leads to irreversible damage of plants communities and other living organisms.

We intend to continue our research in the following directions:

to supply a new data set of the climatic condition of the soil cover in "Kolomna" MSW landfill and in experimental and control areas, particularly humidity, temperature, etc.;

to investigate the microbiological parameters of air and soil condition;

to examine the necrotic leaves tissue;

to study the morphological structure of stomata leaves.

quality of the Mažoji Sruoja River. Environmental Research, Engineering and Management, Volume 73, № 3, Pages 32-44. https://doi.org/10.5755/j01.erem.73.3.16268

Mukhadi Umarov, Musa Taisumov (2012). Medicinal and useful plants introduced in the territory of the Botanical Garden of the Chechen State University. Publishing: Dagestan State University, Pages 90-95.

RD 52.04.186-89. Manual on Air Pollution Control (Part II, III of the Appendix to Part I): developed and introduced by the State Committee for Hydrometeorology of the USSR and the Ministry of Health of the USSR. http://docs.cntd.ru/ document/1200037440

Roman Mamadzhanov, Elena Latushkina. (2016). Design of artificial phytocenoses in the closed MSW landfills. Publishing: UTS Perspektiva, $192 \mathrm{p}$.

Olivia Maamari, Jounaid Maurice, Cedric Brandam, Roger Lteif, Dominique Salameh (2017). Indicators of Sustainable Development for Health Care Waste Treatment Industry. Environmental Research, Engineering and Management, Volume 73, № 2, Pages 7-20. https://doi.org/10.5755/j01. erem.73.2.13399

Prosper Achaw Owusu, Noble Banadda (2017). Livestock wasteto-bioenergy generation potential in Uganda. Environmental Research, Engineering and Management, Volume 73, № 3, Pages 45-53. https://doi.org/10.5755/j01.erem.73.3.14806 